\title{
Preparation and Characterization of the Adducts of Bis(morpholinedithiocarbamato)copper(II) with Nitrogen and Oxygen Donor Ligands
}

\author{
DEEPSHIKHA KHAJURIA*, POOJA SHARMA, NEERUPAMA and RENU SACHAR \\ Department of Chemistry, University of Jammu, Babasaheb Ambedkar Road, \\ Jammu - 180006, India \\ shikha226@gmail.com
}

Received 11 September 2014 /Accepted 25 September 2014

\begin{abstract}
A series of new 1:1 and 1:2 adducts of Bis(morpholinedithiocarbamato)copper(II) with nitrogen and oxygen donors with general formula $\left[\mathrm{Cu}(\text { morphdtc })_{2} \mathrm{~L}\right]$ and $\left[\mathrm{Cu}(\text { morphdtc })_{2} \mathrm{~L}_{2}\right]$ respectively (where $\mathrm{L}=2$-ethylpyridine, 2, 4, 6-collidine, dimethylsulphoxide and hexamethylphosphoramide) have been synthesized. The addition complexes have been characterized by elemental analysis, conductivity measurements, magnetic susceptibility measurements, TGA/DTA, infrared and electronic spectral studies. These studies suggest that 1:1 adducts are paramagnetic and may be assigned square pyramidal structure while 1:2 adducts are paramagnetic in nature and have a distorted octahedral structure. Antifungal activity of some adducts have been carried out against the fungal strain Sclerotium rolfsii.
\end{abstract}

Keywords: Morpholinedithiocarbamato, Ethylpyridine, Morpholine, Dimethylsulphoxide, Hexamethylphosphoramide, Sclerotium rolfsii

\section{Introduction}

Dithiocarbamates are a versatile class of monoanionic 1,1-dithiolato systems involving sulfur donor ligands. A large number of transition metal dithiocarbamate complexes have been synthesized and characterized until now ${ }^{1-3}$. These compounds present striking structural features and have diverse applications such as vulcanization accelerators, fungicides, pesticides, floatation agents and high pressure lubricants ${ }^{4-9}$. They are used as curing agents in rubber processing and in photographic films ${ }^{10,11}$. They play an important role as an adjuvant in the chemotherapy of human cancers; treat acquired immune depressive syndrome and drug resistant fungal infection ${ }^{12-15}$. They are also found to be helpful in the treatment of chronic alcoholism as alcohol aversion therapy ${ }^{16,17}$. They have been widely used in solvent extraction and other analytical procedures

\section{Experimental}

Morpholine $(0.1 \mathrm{~mol}, 9.87 \mathrm{~mL})$ and diethyl ether $(150 \mathrm{~mL})$ were taken in a round bottom flask and the contents were stirred for ten minutes. To this carbon disulfide $(0.1 \mathrm{~mol}, 6 \mathrm{~mL})$ was 
added drop wise with continuous stirring. During the course of the reaction, dithiocarbamic acid was formed. To this, solution of sodium hydroxide $(4 \mathrm{~g})$ prepared in $50 \mathrm{~mL}$ of water was added again with continuous stirring. As a result, two layers, an aqueous layer containing sodium salt of morpholinedithiocarbamate and a clear ethereal layer, were obtained. The aqueous layer was separated from the ethereal layer by using a separating funnel. The solution of sodium salt thus obtained was stored in a tightly stoppered flask.

\section{Preparation of bis(morpholinedithiocarbamato)copper(II) complex}

The morpholinedithiocarbamate complex of copper(II) was prepared by adding an aqueous solution of sodium salt of morpholinedithiocarbamate $(2.14 \mathrm{~g}, 0.02 \mathrm{~mol})$ to an aqueous solution of $\mathrm{CuCl}_{2} .2 \mathrm{H}_{2} \mathrm{O}(8.524 \mathrm{~g}, 0.05 \mathrm{~mol})$ with constant stirring. A brown coloured complex precipitated out immediately which was washed repeatedly with cold distilled water and dried in vacuum over anhydrous calcium chloride. The composition of the complex was established to be $\left[\mathrm{Cu}\left(\mathrm{S}_{2} \mathrm{CNC}_{4} \mathrm{H}_{8} \mathrm{O}\right)_{2}\right]$ by elemental analysis.

\section{Preparation of (1:1) adducts of bis(morpholinedithiocarbamato)copper(II)}

$\mathrm{Cu}$ (morphdtc) $)_{2}(1.007 \mathrm{~g}, 0.0026 \mathrm{~mol})$ was dissolved in $100 \mathrm{~mL}$ of dimethylformamide by stirring. To the resulting solution substituted pyridines [2-ethylpyridine $=0.278616 \mathrm{~g}(0.0026$ mol), 2,4,6-collidine $=0.3150 \mathrm{~g}(0.0026 \mathrm{~mol})$, dimethylsulphoxide $=0.203138 \mathrm{~g}(0.0026 \mathrm{~mol})$, hexamethylphosphoramide $=0.46592 \mathrm{~g}(0.0026 \mathrm{~mol})]$ was added. The mixture was refluxed for about one hour and the contents were kept undisturbed overnight. Brown coloured adduct were obtained which were filtered and dried in a vacuum desiccator over anhydrous calcium chloride.

\section{Preparation of (1:2) adducts of bis(morpholinedithiocarbamato)copper(II)}

$\mathrm{Cu}$ (morphdtc) $)_{2}(1.007 \mathrm{~g}, 0.0026 \mathrm{~mol})$ was dissolved in $100 \mathrm{~mL}$ of dimethylformamide by stirring. To the resulting solution was added substituted pyridines [2-ehtylpyridine= $0.557232 \mathrm{~g}(0.0052 \mathrm{~mol}), 2,4,6$ collidine $=0.630136 \mathrm{~g}$; $(0.0052 \mathrm{~mol})$, dimethylsulphoxide $=$ $0.406276 \mathrm{~g}(0.0052 \mathrm{~mol})$, hexamethylphosphoramide $=0.93184 \mathrm{~g}(0.0052 \mathrm{~mol})]$. The mixture was refluxed for about one hour and the contents were kept undisturbed overnight. Dark brown coloured adduct were obtained which were filtered and dried in a vacuum desiccator over anhydrous calcium chloride.

\section{Method}

Morpholine, nitrogen and oxygen donors were used as such. Metal analysis was done by the reported method Carbon, hydrogen and nitrogen analysis were performed by microanalytical methods. Molar conductivity in chloroform and DMF $\left(10^{-3} \mathrm{M}\right)$ at room temperature was measured using a digital conductivity meter "Century CC 601" and a conductivity cell with a cell constant 1 . Magnetic susceptibility of the complexes was recorded at room temperature by VSM technique. IR spectra of the complexes over the region 4000-400 $\mathrm{cm}^{-1}$ were recorded on Perkin Elemer FTIR spectrophotometer using $\mathrm{KBr}$ disc. The electronic spectra of the complexes were recorded in the range $12500-40000 \mathrm{~cm}^{-1}$ on Systronics 119 UV-Visible spectrophotometer. Thermogravimetric analysis (TGA/DTA) of the complexes was recorded on Linseis STA-PT-thermoanalyzer at $1000{ }^{\circ} \mathrm{C}$ in the Department of Chemistry University of Jammu, Jammu. The antifungal activity of the complexes was tested by poisoned food technique against the pathogenic fungus, Sclerotium rolfsii. All the experiments were carried out at room temperature. 


\section{Results and Discussion}

The complexes were analysed by various analytical and physicochemical techniques and the results show that $\left.[\mathrm{Cu} \text { (morphdtc) })_{2}\right]$ forms $1: 1$ and 1:2 adducts with general formula $\left[\mathrm{Cu}(\text { morphdtc })_{2} \mathrm{~L}\right]$ and $\left[\mathrm{Cu}(\text { morphdtc })_{2} \mathrm{~L}_{2}\right]$ respectively. All the complexes are coloured and stable in air. Conductance measurements were done to ascertain the electrolytic/nonelectrolytic nature of metal complexes. The molar conductivity values were measured in $10^{-3} \mathrm{M}$ chloroform solution is found to be in the range of $8-34 \mathrm{ohm}^{-1} \mathrm{~cm}^{2} \mathrm{~mol}^{-1}$. These values suggest non-electrolytic nature of these adducts ${ }^{18}$.

\section{Preliminary investigations}

The adducts of bis(morpholinedithiocarbamat)copper(II) with various nitrogen and oxygen donors are brown to dark brown in colour. All the adducts are stable in air. They are insoluble in water, methanol, ethanol, acetone etc., partially soluble in chloroform, DMF and DMSO. The elemental analysis reveals that $\mathrm{Cu}$ (morphdtc) $)_{2}$ forms both $1: 1$ and 1:2 adducts with nitrogen and oxygen donors. The 1:1 addition complexes of bis(morpholinedithiocarbamato)copper(II) have been assigned the general formulae $\mathrm{Cu}\left[\left(\mathrm{S}_{2} \mathrm{CNC}_{4} \mathrm{H}_{8} \mathrm{O}\right)_{2} \mathrm{~L}\right]$ whereas the 1:2 adducts have been assigned the formulae $\mathrm{Cu}\left[\left(\mathrm{S}_{2} \mathrm{CNC}_{4} \mathrm{H}_{8} \mathrm{O}\right)_{2} \mathrm{~L}_{2}\right]$ (Table 1).

\section{Magnetic measurements}

The magnetic moments of all the complexes were measured at room temperature and presented in (Table 2). The 1:1 adducts of bis(morpholinedithiocarbamato)copper(II) with nitrogen and oxygen donors exhibit the magnetic moment in the range of 1.78-1.89 B.M. reflecting that these adducts are paramagnetic and may be having five coordinate square pyramidal structures as observed in many low spin square pyramidal complexes of copper(II). While the magnetic moment values for 1:2 adducts come in the range of 1.811.97 B.M. Thus these adducts are paramagnetic having two unpaired electrons and may be assigned 6-coordinated octahedral structure.

\section{Infrared spectra}

The infrared spectra of 1:1 and 1:2 adducts of bis(morpholinedithiocarbamato)copper(II) with primary and secondary amines prepared in the present work were recorded using $\mathrm{KBr}$ pellets in the range $4000-400 \mathrm{~cm}^{-1}$. The IR bands of the free dithiocarbamate ligands on coordination with copper(II) show a shift towards higher wave numbers. In these complexes a strong band observed in the region $1505-1441 \mathrm{~cm}^{-1}$ is attributed to $v(\mathrm{C}-\mathrm{N})$ stretching vibration which lies intermediate between $v(\mathrm{C}-\mathrm{N})$ and $v(\mathrm{C}=\mathrm{N})$ indicating a partial double bond character of the $\mathrm{C}-\mathrm{N}$ bond ${ }^{19-20}$. It shows a positive shift of $25-35 \mathrm{~cm}^{-1}$ in comparison to the corresponding band in the free ligands. A single band of strong intensity was observed in the range 1035-992 $\mathrm{cm}^{-1}$ which may be due to $v(\mathrm{CSS})$ vibration. There is a positive shift of $10-30 \mathrm{~cm}^{-1}$ in comparison to the corresponding band in the free ligands which indicates that the dithiocarbamate ligand coordinates with metal through sulfur atoms. A single absorption in the range $1035-992 \mathrm{~cm}^{-1}$ is indicative of bidentate nature of the dithiocarbamate ligand which is due to equivalent $\mathrm{C}-\mathrm{S}$ stretching vibrations ${ }^{21-24}$. A band of medium to strong intensity, observed in the region $400-426 \mathrm{~cm}^{-1}$, may be assigned to $v(\mathrm{Cu}-\mathrm{S})$ stretching mode (Table 3$)$. 
Table 1. Analytical data of 1:1 and 1:2 adducts of bis(morpholinedithiocarbamato)copper(II) with nitrogen and oxygen donors

\begin{tabular}{|c|c|c|c|c|c|c|c|c|c|c|}
\hline z & \multirow{2}{*}{ Name of the adducts } & \multirow{2}{*}{ Formula } & \multicolumn{4}{|c|}{$\%$ (Found) } & \multicolumn{4}{|c|}{$\%$ (Calculated) } \\
\hline$\dot{s}$ & & & $\mathrm{C}$ & $\mathrm{H}$ & $\mathrm{N}$ & $\mathrm{S}$ & $\mathrm{C}$ & $\mathrm{H}$ & $\mathrm{N}$ & $\mathrm{S}$ \\
\hline 1. & $\begin{array}{l}\text { Bis(morpholinedithiocarbamato) } \\
\text { (2-ethylpyridine) copper(II) }\end{array}$ & $\begin{array}{c}\mathrm{Cu}\left(\mathrm{S}_{2} \mathrm{CNC}_{4} \mathrm{H}_{8} \mathrm{O}\right)_{2} \\
\left(\mathrm{C}_{7} \mathrm{H}_{9} \mathrm{~N}\right)\end{array}$ & 40.24 & 4.04 & 7.48 & 24.87 & 41.25 & 5.05 & 8.49 & 25.88 \\
\hline 2. & $\begin{array}{l}\text { Bis(morpholinedithiocarbamato) } \\
\text { (2,4,6-collidine) copper(II) }\end{array}$ & $\begin{array}{c}\mathrm{Cu}\left(\mathrm{S}_{2} \mathrm{CNC}_{4} \mathrm{H}_{8} \mathrm{O}\right)_{2} \\
\left(\mathrm{C}_{8} \mathrm{H}_{11} \mathrm{~N}\right)\end{array}$ & 41.46 & 4.29 & 7.24 & 24.16 & 42.47 & 5.30 & 8.25 & 25.17 \\
\hline 3. & $\begin{array}{l}\text { Bis(morpholinedithiocarbamato) } \\
\text { (dimethylsulphoxide)copper(II) }\end{array}$ & $\begin{array}{c}\mathrm{Cu}\left(\mathrm{S}_{2} \mathrm{CNC}_{4} \mathrm{H}_{8} \mathrm{O}\right)_{2} \\
\left(\mathrm{C}_{2} \mathrm{H}_{6} \mathrm{SO}\right)\end{array}$ & 29.92 & 3.71 & 5.00 & 33.35 & 30.93 & 4.72 & 6.01 & 34.36 \\
\hline 4. & $\begin{array}{l}\text { Bis(morpholinedithiocarbamato) } \\
\text { (hexamethylphosphoramide)copper(II) }\end{array}$ & $\begin{array}{l}\mathrm{Cu}\left(\mathrm{S}_{2} \mathrm{CNC}_{4} \mathrm{H}_{8} \mathrm{O}\right)_{2} \\
\left(\mathrm{C}_{6} \mathrm{H}_{18} \mathrm{~N}_{3} \mathrm{PO}\right)\end{array}$ & 32.88 & 5.00 & 11.34 & 21.58 & 33.89 & 6.00 & 12.35 & 22.59 \\
\hline 5. & $\begin{array}{l}\text { Bis(morpholinedithiocarbamato)bis } \\
\text { (2-ethylpyridine) copper(II) }\end{array}$ & $\begin{array}{c}\mathrm{Cu}\left(\mathrm{S}_{2} \mathrm{CNC}_{4} \mathrm{H}_{8} \mathrm{O}\right)_{2} \\
\left(\mathrm{C}_{7} \mathrm{H}_{9} \mathrm{~N}\right)_{2}\end{array}$ & 46.86 & 4.64 & 8.29 & 20.26 & 47.87 & 5.65 & 9.30 & 21.27 \\
\hline 6. & $\begin{array}{l}\text { Bis(morpholinedithiocarbamato)bis } \\
(2,4,6 \text {-collidine) copper(II) }\end{array}$ & $\begin{array}{c}\mathrm{Cu}\left(\mathrm{S}_{2} \mathrm{CNC}_{4} \mathrm{H}_{8} \mathrm{O}\right)_{2} \\
\left(\mathrm{C}_{8} \mathrm{H}_{11} \mathrm{~N}\right)_{2}\end{array}$ & 48.54 & 5.02 & 7.88 & 19.32 & 49.55 & 6.03 & 8.89 & 20.33 \\
\hline 7. & $\begin{array}{l}\text { Bis(morpholinedithiocarbamato)bis } \\
\text { (dimethylsulphoxide) copper(II) }\end{array}$ & $\begin{array}{l}\mathrm{Cu}\left(\mathrm{S}_{2} \mathrm{CNC}_{4} \mathrm{H}_{8} \mathrm{O}\right)_{2} \\
\quad\left(\mathrm{C}_{2} \mathrm{H}_{6} \mathrm{SO}\right)_{2}\end{array}$ & 29.89 & 4.14 & 4.14 & 34.31 & 30.90 & 5.15 & 5.15 & 35.32 \\
\hline 8. & $\begin{array}{l}\text { Bis(morpholinedithiocarbamato)bis } \\
\text { (hexamethylphosphoramide)copper(II) }\end{array}$ & $\begin{array}{c}\mathrm{Cu}\left(\mathrm{S}_{2} \mathrm{CNC}_{4} \mathrm{H}_{8} \mathrm{O}\right)_{2} \\
\left(\mathrm{C}_{6} \mathrm{H}_{18} \mathrm{~N}_{3} \mathrm{PO}\right)_{2}\end{array}$ & 34.40 & 5.96 & 14.01 & 16.16 & 35.41 & 6.97 & 15.02 & 17.17 \\
\hline
\end{tabular}

Table 2. Molar conductance and magnetic data of 1:1 and 1:2 adducts of bis(morpholinedithiocarbamato)copper(II) with nitrogen and oxyger donors

\begin{tabular}{clccc}
\hline \multirow{2}{*}{ S.No } & \multicolumn{1}{c}{ Name of the adduct } & Molar conductance & \multicolumn{2}{c}{ Magnetic data } \\
\cline { 4 - 5 } Ohm $^{-1} \mathrm{~mol}^{-1} \mathrm{~cm}^{2}$ & $\mu_{\text {eff }}$ B.M & Temperature, K \\
\hline 1 & Bis(morpholinedithiocarbamato) (2-ethylpyridine)copper(II) & 26 & 1.78 \\
2 & Bis(morpholinedithiocarbamato) (2,4,6-collidine)copper(II) & 18 & 300 \\
3 & Bis(morpholinedithiocarbamato) (dimethylsulphoxide)copper(II) & 17 & 1.83 & 300 \\
4 & Bis(morpholinedithiocarbamato) (hexamethylphosphoramide)copper(II) & 17 & 1.85 & 300 \\
5 & Bis(morpholinedithiocarbamato)bis (2-ethylpyridine)copper(II) & 25 & 1.81 & 300 \\
6 & Bis(morpholinedithiocarbamato)bis (2,4,6-collidine)copper(II) & 17 & 1.86 & 300 \\
7 & Bis(morpholinedithiocarbamato)bis (dimethylsulphoxide)copper(II) & 23 & 1.89 & 300 \\
8. & Bis(morpholinedithiocarbamato)bis (hexamethylphosphoramide)copper(II) & 25 & 1.97 & 300 \\
\hline
\end{tabular}


Table 3. Important IR bands and electronic spectral data of $1: 1$ and $1: 2$ of adducts of bis(morpholinedithiocarbamato)copper(II) with nitrogen and oxygen donors

\begin{tabular}{|c|c|c|c|c|c|c|}
\hline \multirow[t]{2}{*}{$\underset{n}{2}$} & \multirow[t]{2}{*}{ Name of the adduct } & \multirow{2}{*}{$\begin{array}{c}\begin{array}{c}\text { Electronic } \\
\text { spectral data } \\
\mathrm{cm}^{-1}\end{array} \\
v_{1} \\
\end{array}$} & \multicolumn{4}{|c|}{$\begin{array}{l}\text { Vibrational spectral data } \\
\qquad \mathrm{cm}^{-1}\end{array}$} \\
\hline & & & $v(\mathrm{~N}-\mathrm{H})$ & $v(\mathrm{C}-\mathrm{N})$ & $v(\mathrm{CSS})$ & $v(\mathrm{Cu}-\mathrm{S})$ \\
\hline & $\begin{array}{l}\text { Bis(morpholinedithiocarbamato) } \\
\text { (2-ethylpyridine)copper(II) }\end{array}$ & 16889 & 3328 & 1513 & 1025 & 419 \\
\hline & $\begin{array}{l}\text { Bis(morpholinedithiocarbamato) } \\
\text { (2,4,6-collidine)copper(II) }\end{array}$ & 16733 & 3268 & 1498 & 1015 & 422 \\
\hline & $\begin{array}{l}\text { Bis(morpholinedithiocarbamato) } \\
\text { (dimethylsulphoxide)copper(II) }\end{array}$ & 16830 & 3249 & 1499 & 1017 & 421 \\
\hline & $\begin{array}{l}\text { Bis(morpholinedithiocarbamato) } \\
\text { (hexamethylphosphoramide)copper(II) }\end{array}$ & 16802 & 3247 & 1498 & 1029 & 420 \\
\hline 5. & $\begin{array}{l}\text { Bis(morpholinedithiocarbamato)bis } \\
\text { (2-ethylpyridine)copper(II) }\end{array}$ & 15246 & 3312 & 1496 & 1017 & 419 \\
\hline & $\begin{array}{l}\text { Bis(morpholinedithiocarbamato)bis } \\
(2,4,6 \text {-collidine)copper(II) }\end{array}$ & 15250 & 3308 & 1495 & 1015 & 422 \\
\hline 7. & $\begin{array}{l}\text { Bis(morpholinedithiocarbamato)bis } \\
\text { ( dimethylsulphoxide)copper(II) }\end{array}$ & 15247 & 3337 & 1497 & 1016 & 420 \\
\hline 8. & $\begin{array}{l}\text { Bis(morpholinedithiocarbamato)bis } \\
\text { (hexamethylphosphoramide)copper(II) }\end{array}$ & 15323 & 3346 & 1490 & 1014 & 421 \\
\hline
\end{tabular}

\section{Electronic spectra}

The electronic spectra of 1:1 and 1:2 adducts of $\mathrm{Cu}(\text { morphdtc })_{2}$ with nitrogen and oxygen donors were recorded in chloroform. 1:1 Addition complexes of $\mathrm{Cu}$ (morphdtc) $)_{2}$ show a broad band with maximum intensity centered around $16000 \mathrm{~cm}^{-1}$ which can be assigned to ${ }^{2} \mathrm{~B}_{1} \rightarrow{ }^{2} \mathrm{E}\left(\mathrm{v}_{1}\right)$, suggesting a square pyramidal geometry around $\mathrm{Cu}(\mathrm{II})$ ion. A weak shoulder at around $11000 \mathrm{~cm}^{-1}$ is also shown by these complexes. On the other hand 1:2 adducts of $\mathrm{Cu}$ (morphdtc) $)_{2}$ show a broad absorption band appearing in the range $14392-15891 \mathrm{~cm}^{-1}$. This band, regarded as "copper band" is an average of two transitions ${ }^{2} \mathrm{~B}_{1} \rightarrow{ }^{2} \mathrm{~B}_{2}$ and ${ }^{2} \mathrm{~B}_{1} \rightarrow{ }^{2} \mathrm{E}$. These transitions suggest an octahedral geometry for these $\mathrm{Cu}(\mathrm{II})$ adducts. The electronic spectra of $1: 1$ and $1: 2$ adducts of $\mathrm{Cu}(\text { morphdtc })_{2}$ are presented in (Table 3$)^{25-26}$.

\section{Thermogravimetric analysis}

The TG curve of the adduct shows an initial weight loss of $18.7 \%$ is observed at around $350{ }^{\circ} \mathrm{C}$ due to the loss of 3-ethylpyridine molecules (calculated weight loss $=21.63 \%$ ). Then a continuous weight loss of $59.7 \%$ is observed due to the loss of $\mathrm{C}_{10} \mathrm{H}_{16} \mathrm{~N}_{2} \mathrm{~S}_{3} \mathrm{O}_{2}$ moiety (calculated weight loss $=59.04 \%$ ) and the resultant weight of $21.6 \%$ corresponds to the formation of a stable sulphide $\mathrm{CuS}$ at a temperature of $964{ }^{\circ} \mathrm{C}$ (calculated weight $=19.93 \%$ ) (Figure 1).

\section{Biological studies}

The antifungal activity of the adducts was tested by poisoned food technique against the pathogenic fungus Sclerotium rolfsii. The linear growth of the fungus in controlled manner was recorded at different concentration of the adducts. The growth inhibition of Sclerotium rolfsii over control was calculated (Table 4). It is found that on increasing the concentration of the adducts, the colony diameter of the fungus decreases and hence percent inhibition increases (Figure 2). The growth inhibition of Fungus over control was calculated as: 


\section{$\%$ Inhibition $(\mathrm{I})=\mathrm{C}-\mathrm{T} / \mathrm{C} \times 100$}

Where $\mathrm{I}=$ percent inhibition, $\mathrm{C}=$ mean growth of fungus (in $\mathrm{mm}$ ) in control and $\mathrm{T}=$ mean growth of fungus(in $\mathrm{mm}$ ) in treatment

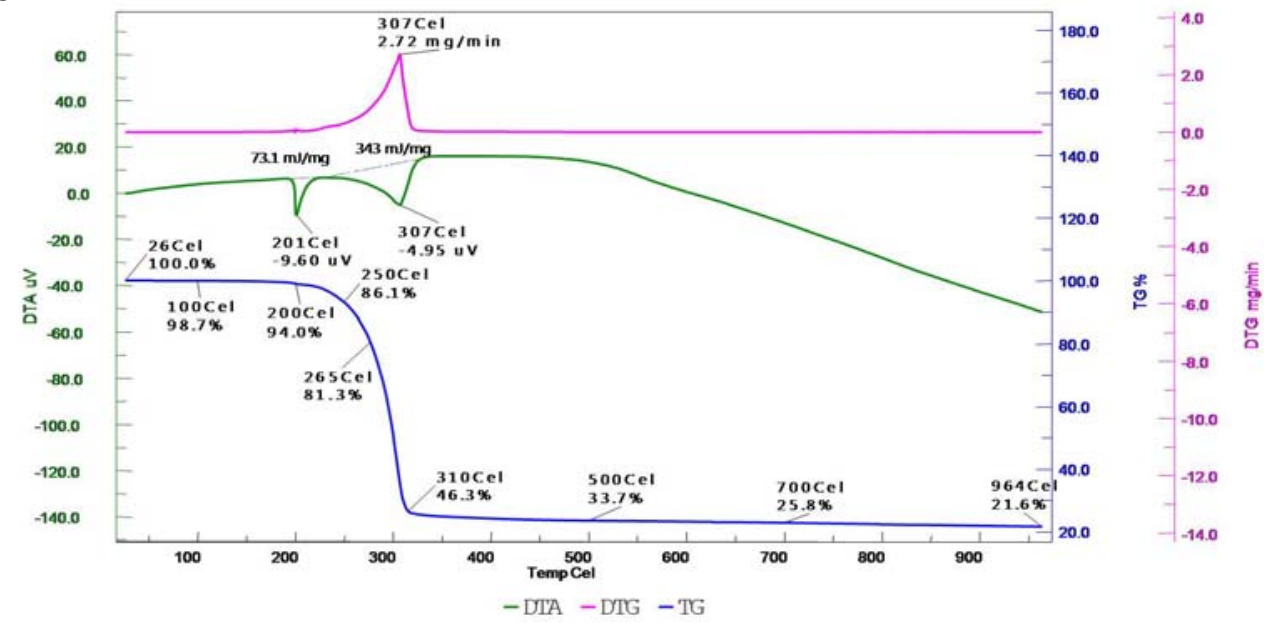

Figure 1. TGA-DTA curve of bis(morpholinedithiocarbamato)bis(3-ethylpyridine)copper(II)

Table 4. In vitro evaluation against Sclerotium Rolfsii, Mean Colony Diameter $=79.5 \mathrm{~mm}$

\begin{tabular}{ccccc}
\hline S.No. & Name of the adduct & $\begin{array}{c}\text { Concentration, } \\
\mathrm{ppm}\end{array}$ & $\begin{array}{c}\text { Colony } \\
\text { diameter, } \\
\mathrm{mm}\end{array}$ & $\begin{array}{c}\% \text { inhibition } \\
(\mathrm{I})=[(\mathrm{C}-\end{array}$ \\
$\mathrm{T}) / \mathrm{C}] \times 100$
\end{tabular}

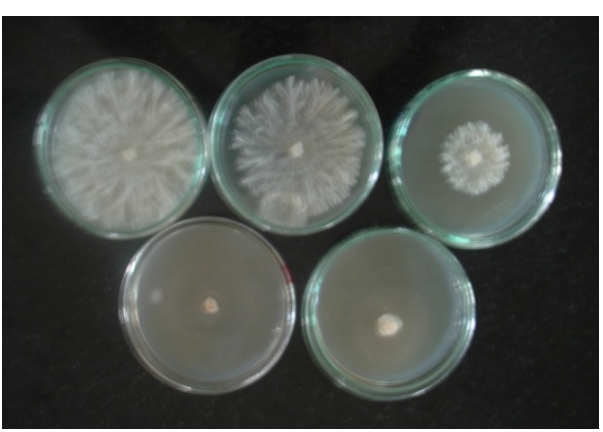

( a)

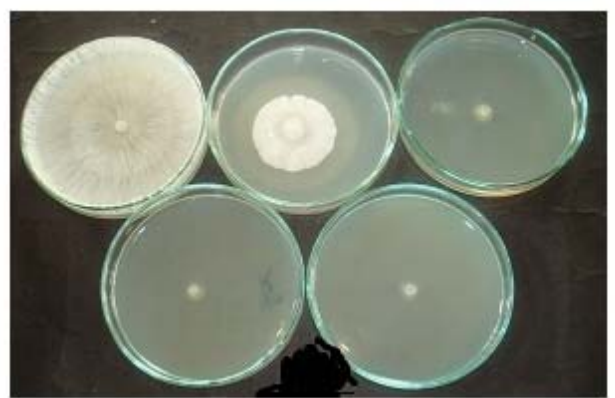

(b)

Figure 2. Antifungal activity of the adducts (a) Bis(morpholinedithiocarbamato)(2ethylpyridine)copper(II), (b) Bis(morpholinedithiocarbamato)bis(2,4,6-collidine)copper(II) 


\section{Conclusion}

On the basis of above studies it is found that $1: 1$ and 1:2 adducts of bis(morpholinedithiocarbamato)copper(II) are paramagnetic in nature having square pyramidal and distorted octahedral geometry respectively. The complexes also show considerable antifungal activity.

\section{References}

1. Ondrusova D, Jona E and Simon P, J Therm Anal Cal., 2002, 67, 147.

2. Daniel K G, Chen D, Orlu S, Cui Q C, Miller F R and Dou Q P, Breast Cancer Res., 2005, 7(6), 897-908.

3. Sarwar M, Ahmad S, Ahmad S, Ali S and Awan S A, Trans Met Chem., 2007, 32(2), 199-203; DOI:10.1007/s11243-006-0148-4

4. Kalia S B, Kaushal G, Sharma D K and Verma B C, Synth React Inorg Met-Org Nano-Met Chem., 2005, 35, 181.

5. Cervantes G, Moreno V, Molins E and Miravitlles C, Metal Based Drugs, 1997, 4(6), 317-325.

6. Mauclaire, Laurent and Berthommier, Eric FR Appl., 2000, 15, 57; Chem Abstr., 2002, 137, $14843 \mathrm{~m}$.

7. Neves A, Rossi L M, Bortoluzzi A J, Mangrich A S, Haase W and Werner R, J Brazil Chem Soc., 2001, 12, 747; Chem Abstr., 2002, 136, 144232 b.

8. Arora C L and Kaur J, Asian J Chem., 1993, 5, 473-476.

9. Coucouvanis D, Prog Inorg Chem., 1970, 11, 233-371.

10. Datta R N, Das P K and Basu D K, Rubber Chem Technol., 1984, 57, 879.

11. Cavalheiro E T G, Ionashiro M, Marino G, Berviglieri S T and Chierice G O, J Braz Chem Soc., 1999, 10, 65.

12. Reisinger E C, Kern P, Ernst M, Bock P, Flad H D and Dietrich M. Lancet, 1990, 335(8691), 679-882; DOI:10.1016/0140-6736(90)90802-C

13. Gandara D R, Perez E A, Weibe V and Gregoriom M W De, Semin Oncol., 1991, 18, 49-55.

14. Kim C H, Kim J H, Xu J, Hsu C Y and Ahn Y S, Blackwell Synergy: J Neurochem., 1999, 72(4), 1586-1592.

15. Sauna Z E, Shukla S and Ambudkar S V, Mol Bio Syst Royal Soc Chem., 2005, 1(2), 127-134; DOI:10.1039/B504392A

16. Fischer C M, Arch Neurol., 1989, 46(7), 798-804.

17. Thorn G D and Ludwig R A, The Dithiocarbamates and Related Compounds; New York, 1962.

18 Geary W J, Coord Chem Rev., 1971, 7(1), 81-122; DOI:10.1016/S00108545(00)80009-0

19 Bradley D C and Gitlitz M H, J Chem Soc (A), 1969, 1152; DOI:10.1039/J19690001152

20 Golcu A. Trans Met Chem., 2006, 31(3), 405-412; DOI:10.1007/s11243-006-0009-1

21 Fabretti A C, Forghieri F, Giusti A, Preti C and Tosi G, Inorg Chim Acta, 1984, 86(2), 127-131; DOI:10.1016/S0020-1693(00)82333-6

22 Brinkhoff H C and Grotens A M. Recl Trav Chim Pays Bas., 1971, 90(3), 252-257; DOI:10.1002/recl.19710900303

23 Golding R M, Harris C M, Jessop K J and Tennant W C, Aust J Chem., 1972, 25(12), 2567-2576;DOI:10.1071/CH9722567

24 Bonati F and Ugo R, J Organomet Chem., 1967, 10(2), 257-268; DOI:10.1016/S0022-328X(00)93085-7

25. Duggan M, Ray N, Hathaway B J, Tomlinson G, Brint P and Pelin K, J Chem Soc., Dalton Trans., 1980, 8, 1342-1348; DOI:10.1039/DT9800001342

26. Hathaway B J, Billing D E, Nicholls P and Procter I M. J Chem Soc (A), 1969, 319325; DOI:10.1039/J19690000319 